\title{
Beyond Lack and Excess: Other Architectures/Other Landscapes*
}

\author{
GÜLSÜm Baydar NalbantoĞLu, Bilkent University, Turkey
}

\begin{abstract}
Familiar binary categories of architecture such as Western/regional, high style/vernacular and modern/primitive are crucial in guarding its disciplinary boundaries. In the first part of my article, by analyzing a number of paradigmatic architectural texts, I argue that notions of lack and excess are instrumental in maintaining the largely superimposed binary constructions of West/non-West and architecture/nonarchitecture. Then, through a particular reading of a non-Western site, I explore ways of rethinking the categories of architecture and non-Western beyond such binary oppositions.
\end{abstract}

I WANT TO START BY ADDRESSING A TIRED QUESTION THAT HAS BEEN REpeatedly asked by the theorists, practitioners, and educators of the architectural discipline: What is architecture? Like any identity question, What is architecture? implies boundaries, i.e., inclusions and exclusions. It indicates a desire to carve a space for "architecture" from an undecipherable plenitude that includes "nonarchitecture." This is a desire to delineate, to control, to judge. The binary logic that separates architecture from nonarchitecture sets up a series of categories that have been critical in addressing my original question. Architecture can only be identified when nonarchitecture is properly named. A series of oppositions that have been constructed since the eighteenth century, such as architecture/ building, high-style/vernacular, modern/primitive, and Western architecture/non-Western architecture, serve precisely that purpose. The first term of each pair unquestionably falls into the accepted parameters of the architectural discipline. The second terms, on the other hand, have been a continuous burden on it. These are the terms that do not clearly fall inside or outside of architecture. They lie at its constitutive edges.

A number of theorists have recently addressed the issue of disciplinary boundaries in the context of Western architectural thought. Karen Burns, for example, argues that "building" is the excluded term that enables the category of architecture; it is "a space continually invoked as outside architecture's own internal space." She thinks of architecture as an identity category and signification rather than a stable and autonomous entity. Elizabeth Grosz, on the other hand, questions whether it is possible for architecture to ask what is different from and beyond it. ${ }^{2}$ Here I want to address the relationship between Western architecture and the categories of the non-West and the vernacular. I am interested in the former's continual invocation of the latter as its constitutive edges. I argue that, at one level the non-West and the vernacular serve the purpose of reinforcing Western architecture's supposed centrality. These provide the sites to which Western architecture can penetrate. They

Journal of Architectural Education, pp. 20-27

(C) 2000 ACSA, Inc. signify architecture by being its other, its lack. As such, architecture needs to make them appear as such. ${ }^{3}$ I am interested in the mechanisms by which the construction of this appearance works and also in possible ways of thinking about architecture differently.

Following Burns and others, my argument is structured on the premise that architecture, as an identity category, can only be defined in relation to an entire network of other identity categories. It is not an autonomous disciplinary enclosure that controls privileged access. Hence, any answer to the question What is architecture? is bound to point to a meconnaisance based on a number of premises other than mine. The latter form the foundational myths of the discipline, which had been firmly established in the West by the nineteenth century. These can arguably be summarized as the primacy of vision, the autonomy of architectural form, and the linear history of the master subject. ${ }^{4}$ Any answer to What is architecture? in the Western theoretical heritage is guarded by these premises. The latter become particularly significant and critical in considering the primal scene when Western architecture encountered, and cast its gaze on, other, that is, non-Western architectural traditions. That is the historical moment not only when Western architecture identified itself as such but also when non-Western architectural scenes were placed in the position of being looked at. I use the term gaze in the Lacanian sense here. "In the scopic regime," contends Jacques Lacan, "the gaze is outside, I am looked at, that is to say, I am a picture. . . What determines me, at the most profound level, in the visible, is the gaze that is outside." In his model, from the moment the subject is looked at, s/he tries to adapt to the gaze. The gaze is everywhere and nowhere. It is apprehended more by its effects than by its source. When a certain body of knowledge, which had identified and established itself as architecture in the Western world prior to colonization, encountered an other, the two terms, "architecture" and "the West," coalesced in unprecedented ways. I would argue that the encounter between Western architecture and its outside is also an encounter between architecture and its outside. It marks the moment when the architectural gaze is cast on other territories than the West and when other architectures became uncomfortably visible. If, as Lacan contends, desire is bound up with the desire of the other, it is set into motion in the architectural field in unprecedented ways. How then, does a particular architectural identification that is based on the exclusion of desire from its constitutive boundaries perpetuate its seemingly self-grounded autonomy?

By way of addressing this question I will focus on two paradigmatic architectural texts: Sir Banister Fletcher's A History of Architecture on the Comparative Method for the Student Craftsman, 
and Amateur, and Bernard Rudofsky's Architecture without Architects: A Short Introduction to Non-pedigreed Architecture. ${ }^{6}$ The first one is a canonical text that marks one of the earliest introductions of non-Western architectural cultures in a historical survey. ${ }^{7}$ The second one pioneers the celebration of vernacular buildings by the architectural discipline. My reading of these texts will be intentionally selective and partial. I will focus only on certain aspects of each and ignore others in a search for ways of undoing the architectural gaze that produces the binary pairs of West/non-West and architecture/nonarchitecture.

\section{Self/Other: Desiring History}

One of the earliest Western architectural surveys to address nonWestern architectural cultures is written by Sir Banister Fletcher. The 1901 edition of his monumental survey A History of Architecture on the Comparative Method for the Student Craftsman, and Amateur includes Indian, Chinese, Japanese, Central American, and Saracenic architectural cultures as well as the standard survey of European styles that had been included in the earlier editions. Fletcher curiously gathers the new additions under a section entitled, "non-historical styles." The prefix "non" signifies lack. It seems that, to be constituted as the guarantor of architecture's autonomy, nonWestern architectures have to be what Western architecture is not. Fletcher explains: "These non-historical styles can scarcely be as interesting from an architect's point of view as those of Europe, which have progressed by the successive solution of construction problems, resolutely met and overcome; for in the East decorative schemes seem generally to have outweighed all other considerations." ${ }^{8}$

Fletcher was certainly not alone in his concern with decorative schemes. The relationship between construction and ornament had been a continuous preoccupation of Western architectural scholarship since the previous century. In an architectural historical context, Fletcher's reknowned predecessor James Fergusson had argued that "a building may be said to be an object of architectural art in the proportion in which the artistic or ornamental purposes are allowed to prevail over the mechanical; and an object of engineering skill, where the utilitarian exigencies of the design are allowed to supersede the artistic." As a typical nineteenth-century architect, Fergusson uses the figure of ornament in defense of architecture against engineering. Even so, following an analysis of the Parthenon, Cistercian monasteries, and the Stonehenge, he argues that when the "ornament is elegant itself, and appropriate to the construction and to the purposes of the building ... the temple or

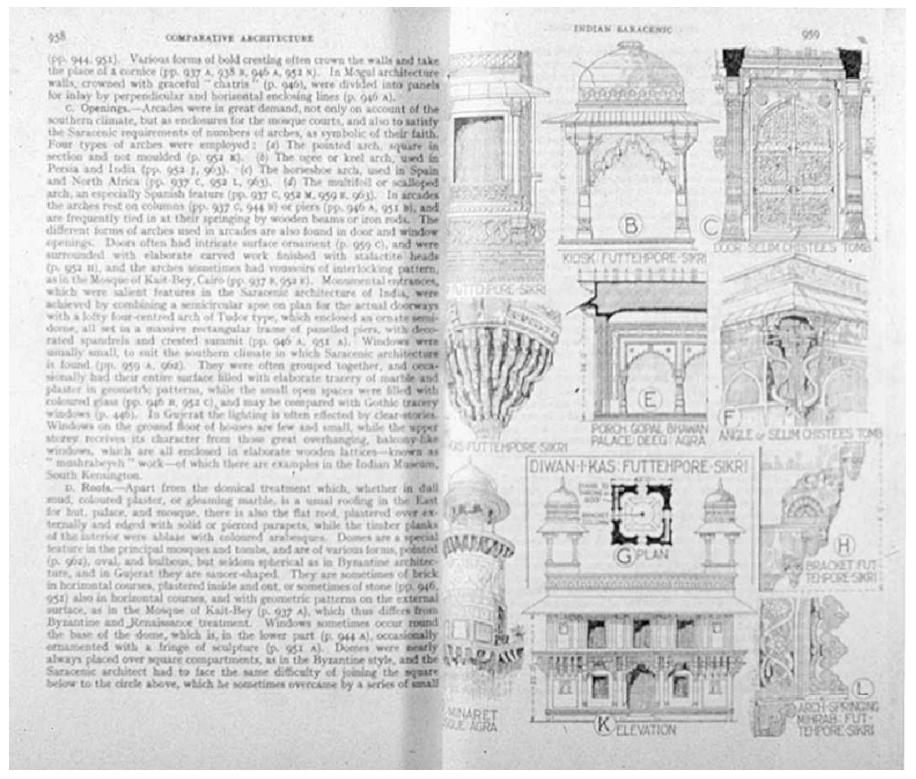

1. Fletcher's illustrations of ornamental details from Indian Saracenic architecture. From Sir Banister Fletcher, A History of Architecture on the Comparative Method for the Student, Craftsman and Amateur (London: B. T. Batsford Ltd., 1954).

the cathedral ranks among the highest objects of the art, and becomes one of the noblest works of man." Like Fletcher, construction and function are two of his primary concerns in rendering ornamentation acceptable. Unlike Fletcher, however, Fergusson does not refrain from classifying Egyptian, Greek, and Gothic architectures with the buildings of "half-civilized inhabitants of India, the stolid Tartars of Thibet and China, and the savage Mexicans," all of which "succeeded in erecting great and beautiful buildings." 10 Besides his colonial cultural biases, Fergusson has a relativist perspective that does not superimpose architectural and cultural identities as easily as his successor would do.

According to Fletcher, however, non-Western styles are distinctly different from Western ones in that they lack history and are marked with ornamental excess (Figure 1). "Lack" and "excess" are terms that mark the exclusions in the Albertian definition of beauty. ${ }^{11}$ If non-Western architectures can only be described on the basis of lack and excess, they should not be worthy of consideration as architecture. In this respect, Fletcher's use of such derogatory terms as "tortured," "bizzare," "striving after excess," and "grotesque" in describing non-Western buildings is hardly surprising. ${ }^{12}$ Besides these, however, he uses other qualifications like "bewildering richness," "grandeur," and "majestic beauty," which indicate intrigue rather than contempt.

Ambivalence of opinion on other cultures may be seen commonplace for a Western historian coming from a long heritage of colonial scholarship. Fergusson, too, expresses such ambivalence in his work on Indian architecture, when he says: "It cannot, of course, be for one moment contended that India ever reached the intellectual supremacy of Greece, or the moral greatness of Rome; but, though on a lower step of the ladder, her arts are more original and more varied, and her forms of civilisation present an ever-changing variety, such as 
are nowhere else to be found." ${ }^{13}$ In his evaluation, Fergusson separates architectural from cultural identity and favors the former while degrading the latter. Fletcher's ambivalence lies in his evaluation of architecture itself as a source of both degradation and praise.

I am interested in Fletcher's simultaneous fascination and unease with what he pathologizes as lack and excess in nonhistorical styles. It seems worthwhile to explore how these terms figure in his discourse and in the construction of the West/non-West and architecture/nonarchitecture binaries. I would argue that, in Fletcher's discourse, lack serves for Western architecture's attributes to be oppositionally articulated while excess renders non-Western architectures adequate to the colonizer's desire. ${ }^{14}$ After all, European styles were qualified as historical only when an oppositional relationship with non-European styles appeared on the agenda. Western architecture had to redefine its identity in positive terms in relation to an other that lacks positivity. In other words, the label "historical styles" becomes possible only after naming non-Western styles as nonhistorical. The attribution of lack to the other serves to positively identify the self. ${ }^{15}$ In Fletcher's discourse, the lack of historicity is complemented with an excess of ornamentation. Lack needs to be masked. What is noted as excess in the other is also the cause of pleasure as its extravagance covers over the lack.

Fletcher does not dwell upon such notions in his book. $\mathrm{He}$ quickly dispenses with his momentary pleasure by submitting nonWestern architectures under the same framework of analysis as the rest. ${ }^{16}$ The other enters the domain of architecture in terms that have already been established prior to its appearance. Yet the source of Fletcher's pleasure lies in the excess that architecture-as-he-knows is unable to represent. The architectural gaze that is cast over his interpretation of the non-Western scene enables him to recognize excess but also to cover over his momentary pleasure.

As a final note, the tight connection between architectural production and theory and historiography during the late nineteenth and early twentieth centuries can hardly be overlooked. Both Fergusson and Fletcher were actively involved with contemporary practice. One might argue that their attitude towards non-Western architectures was partially rooted in the orientalist practices of their Western contemporaries. Indeed such figures as George Aitchison, William Burges, and Thomas Ambler were prolific practicioners of various Islamic traditions during the second half of the nineteenth century. At that time Fergusson, who worked as general manager for the Crystal Palace Company, was recommending his contemporaries to take up the Renaissance style as sensible, strong, and durable in both form and decoration. ${ }^{17}$ Fletcher, on the other hand, praised Louis Sullivan's nonrevivalist Transportation building as "the first rose of summer to the jaded European." 18 There was clearly no room for ambivalence in relation to the non-Western styles when Western architectural practice was in question. Practice took the form of either romanticized attachment or contemptuous denial.

\section{Other/Self: Desiring Architecture}

The nineteenth-century colonial architectural gaze turned to the non-West for its monumental gestures, i.e., palaces, temples, and mosques. Historically, Fletcher's career marked the highlight of this interest as an academic pursuit. I have explored how his work related to defining the boundaries of the architectural discipline. Two key notions of his analysis-lack and excess—-seem to reappear as pertinent tools in problematizing the proper boundaries of architecture. I will make a historical leap now to analyze a different architectural moment that takes non-Western vernacular architectures, rather than monuments, as Western architecture's other. My focus here will be a paradigmatic exhibition at the New York York Museum of Modern Art in 1964. Entitled "Architecture without Architects," the exhibition contained over 150 photographs of anonymous buildings and settings taken by architect Bernard Rudofsky. This is not an isolated moment of curiosity in the history of Western architecture. The story of the exhibition dates back to the 1940s, when International Style modernism was taken to task even by its founding fathers. ${ }^{19}$ By the end of the 1960 s, vernacular architecture was established as an academic field of study on its own. ${ }^{20}$

Rudofsky's exhibition was staged in the manner of an architectural manifesto. The architect was critical of Western architecture's concern with "a few select cultures ... a small part of the globe ... a who's who of architects who commemorated power and wealth, and an anthology of buildings of, by and for the privileged." ${ }^{21}$ Through his exemplary effort, the audience of the Museum of Modern Art was introduced to the other half of the built environment untouched by the master architects' intervention.

Recent scholarship reveals that Rudofsky's project exceeds the field of architecture as such. In 1944, he organized an exhibition "Are Clothes Modern?" in the same setting. By juxtaposing ethnographic and modern artifacts of similar appearance, he set out to illustrate that modernist ideals of rationality and functionalism were but myths. Felicity Scott argues that, other contemporary critics of modern architecture sought to integrate functionalism with transcendent beauty but, for Rudofsky, "a line of escape from the effects of the International Style was the prospect to be opened up through eliciting that 
irrational quality of desire underneath 'aesthetics and utility.' "'22 Following Scott's argument, Rudofsky's appeal to vernacular architecture is apparently tied to his broader interest in the erotic and the primitive as the suppressed aspects of the International Style. Shelter, apparel, and food for him were interrelated as the sources of "sensous pleasure for which they were invented in the first place." ${ }^{23}$ This line of argument strangely aligns Rudofsky with Fletcher in the recognition of the source of pleasure in the other. While Fletcher recognizes this source only to suppress it, Rudofsky capitalizes on it as a means to pervert the conformity to disciplinary regulation. If, indeed, Rudofsky's project was to uncover an irreducable source of "unsublimated fetishism" in non-Western vernacular architectures, it was too easily recuperated into the architectural canon that is structured upon the denial of desire. Felicity Scott's article concludes with a postscript on the recuperation of Rudofsky's sandal designs by the functionalist rhetoric of Laszlo Moholy-Nagy. It seems that Rudofsky's search for an "untransposable fetish" was impossible as fetish, by definition, is the substitute for a perceived lack. The fetish is always already located in the symbolic order.

It is difficult to disagree with Rudofsky's reaction against certain aspects of the architectural canon. In his haste to correct this "error," however, Rudofsky overlooks the fact that the canon is also based on the privileging of the visual, notions of origin and progress, and a binary system of thinking. For Rudofsky's system, too, is structured around the binary opposites of high-style/vernacular; authored/anonymous; individual/communal; the "architectural blight in industrial countries" versus the "serenity of the architecture in so-called underdeveloped countries." The powerful black and white images in Architecture without Architects display intricately sculpted buildings and settlements that merge comfortably into their natural settings.

Rudofsky's characteristically humanist approach enables him to homogenize local architectural traditions based on a naturalistic essence. In this architectural narrative, Spanish streets, and Syrian water wheels, Anatolian carved dwellings, and African granaries exist side by side, all set against the notion of insensitive, commercialized, and industrialized qualities of a generalized notion of Western architecture. The photo captions emphasize sculptural and esthetic qualities, permanence, exceptional imagination, and artistic insight. Rudofsky's agenda becomes clear when he states "The present exhibition is the vehicle of the idea that the philosophy and know-how of the anonymous builders present the largest untapped source of architectural inspiration for industrial man." ${ }^{24}$

Rudofsky's heroic project then, makes him the living agent and witness for otherwise lost architectural traditions. But lost to whom? At one important level, his enterprise is but one instance whereby a narrative of local traditions serves as a critique of Western architecture's self-made trajectory. Rudofsky's oppositional narrative originates from Western architecture's founding principles based on the aura of the autonomous architectural object. The vernacular is named and transformed, through the architectural gaze, into a standing reserve for the pleasure of the architect. I think that is precisely the reason for the widespread circulation of Architecture without Architects among practicing Western architects. Emphasizing the experiential qualities, human scale, and visual richness of vernacular buildings, Rudofsky's approach was greatly acclaimed by the critics of the modernist vocabulary. ${ }^{25}$

Rudofsky's approach to vernacular buildings has been substantially criticized by his successors as devoid of contextual analysis. Unsurprisingly perhaps, the underlying premises of his project perpetuates in architectural discourse. A leading scholar in the field, Paul Oliver, played a significant role in shifting the focus from the sensual aesthetics of vernacular objects to their environmental, material, and cultural context. ${ }^{26} \mathrm{His}$ is a commendable project in questioning the autonomy of architectural form. Yet the binary thinking that places the evils of capitalism and industrialization on one side, and the potency of indigenous cultures on the other remains unchallenged. Oliver seems to echo Rudofsky's "us versus them" logic when he states that "by studying the qualities that shape the dwelling of differing societies . . we may be more effective in assisting them in gaining appropriate living conditions-and in the process, learn more about our own [Emphases mine]. ${ }^{27}$ I would now like to return to the notions of lack and excess in the identification of indigenous architectures as proper architecture's other.

Rudofsky is one of the pioneering figures who included architecture without architects (i.e., architecture that lacks architects) in the grand narrative of architecture with architects. The two terms that structured Fletcher's discourse, lack and excess, can be read differently in Rudofsky's narrative. This time it is Western architecture that lacks the wisdom of anonymous builders and is in excess of industrialization. In a manner that is strikingly different than Fletcher's, Rudofsky's source of pleasure, too, is rooted in what he identifies as excess, i.e., his camera-a product of Western industrial technology. For it is his dramatically shot black-and-white images that render architecture without architects desirable to the architectural audience. Let me illustrate.

In one striking instance in Architecture without Architects, facing pages show two views of a Sudanese tribal settlement: a bird'seye view and a close-up (Figure 2). "What at first glance appears to be mere debris," Rudofsky discloses, houses a "highly sophisticated 


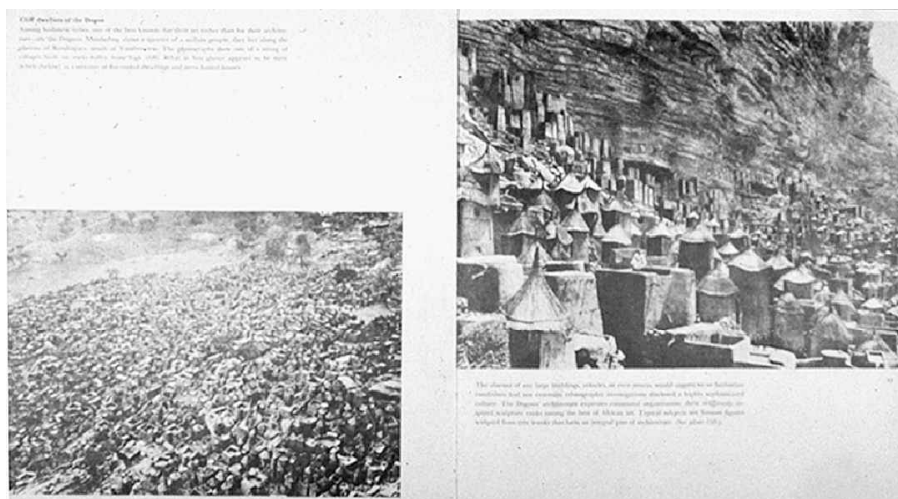

2. Rudofsky's illutrations of the Sudanese tribal settlement. From Bernard Rudofsky, Architecture without Architects: A Short Introduction to Non-pedigreed Architecture (New York: Doubleday, 1964).

culture" known to produce some of the best examples of African art. ${ }^{28}$ The eye of the camera illuminates the tribal settlement in the manner of a projector. In doing so it explicates secrets, restores identities, and corrects mistakes. In both cases, then, the illumination that lights up the tribal settlement has its origin elsewhere. The camera's double-move removes the viewer twice from the tribal settlement. Rudofsky literally shows two possible ways of seeing it. His first shot shows what the Sudanese settlement is not, i.e., nonarchitecture. The second one shows what it is, i.e., architecture. Rudofsky's look enables him to project a different image on the screen, of the same object that the gaze had denied architectural status. His camera enables him to return life (architecture) to the dead (debris).

But does it?

I would argue that the architectural gaze that is cast over Rudofsky's camera participates in a double-murder-double death. The Sudanese tribal settlement is killed once by analogy to debris and once more by analogy to architecture. Both Roland Barthes and Kaja Silverman dwell on death in relation to photography. Barthes contends that photography transforms subjects into objects. Being photographed, he says, one is neither subject nor object, but a subject who feels s/he is becoming an object. The moment of becoming a specter, to him, is an experience of a microversion of death. ${ }^{29}$ Silverman, on the other hand, argues that both the camera and the gaze confer a specular body on the subject, which concurs with the death of its existential body. ${ }^{30}$ In both cases, death is associated with the silencing of a speaking, feeling subject turned into a frozen image.

I do not suggest, of course, that the Sudanese tribal settlement is marked by an essential identity that is murdered by the architect's camera. Even when we accept that identities are effects of language, the Sudanese subjects who had occupied Rudofsky's settlement are inaccessable to us. What is important to me is that each architectural recording inscribes another layer of meaning on the site or building that is frozen by the camera. I refer to this inscription, which remains unproblematized by the recorder, in claiming that rather than bestowing immortality, architectural re- cording marks the death of buildings. It affirms architecture through death. In using the photographs to name the Sudanese buildings as either debris or architecture, Rudofsky forecloses other possible identifications. His project aims at the legitimation of vernacular buildings through their identification as architecture. As such, the photographs of the Sudanese settlement are presented to speak their photographer's language, i.e., the language of architecture. It is in that sense that I associate Rudofsky's gesture with silencing and death. Yet such records are necessary to confer architectural identity on any building. It is through these records that buildings are recognized as architecture. The inclusion then, of the Sudanese tribal settlement into the category of architecture involves a violent act of exclusion. Both the category of architecture and the Sudanese tribal settlement are thus deprived from other possible interpretations and identifications that might have proliferated from the encounter between architecture and its outside, architecture and nonarchitecture.

Rudofsky is clearly capable of seeing other than what is given to be seen. Yet his look is governed by the imperative to return to those images that provide fantasmatic origins for his own imaginary identification. The non-West, the primitive and the vernacular are very often juxtaposed as the origin of an fetishized "natural" identity that precedes the industrialized world of the modern West. ${ }^{31}$ In Rudofsky's discourse, the familiar binary pairs-Western and regional, international and national, global and local—overlap with another set of pairs consisting of disciplinary terms such as architecture and building, high-style and vernacular, modern and primitive. If Fletcher privileges and idealizes one side of the equation, Rudofsky does the opposite. So far I explored the mechanisms by which these idealizations are constructed and argued that the terms of the equation are kept intact in both cases. The boundaries of the architectural discipline are reinforced by the naming of an other in two different ways. Fletcher ascribes a positive identity to Western architecture by identifying an absence in the other. Rudofsky, on the other hand, incorporates the vernacular as the lost origin of the modern West. Lack and excess organize their discourses in different but parallel ways.

\section{Other Architectures/Other Landscapes}

Fletcher's "non" of the "nonhistorical," Rudofsky's "without" of "architecture without architects," and the "non" of the term "nonWestern" overlap in interesting ways. All are based on a notion of lack that juxtaposes architecture with the West and nonarchitecture 


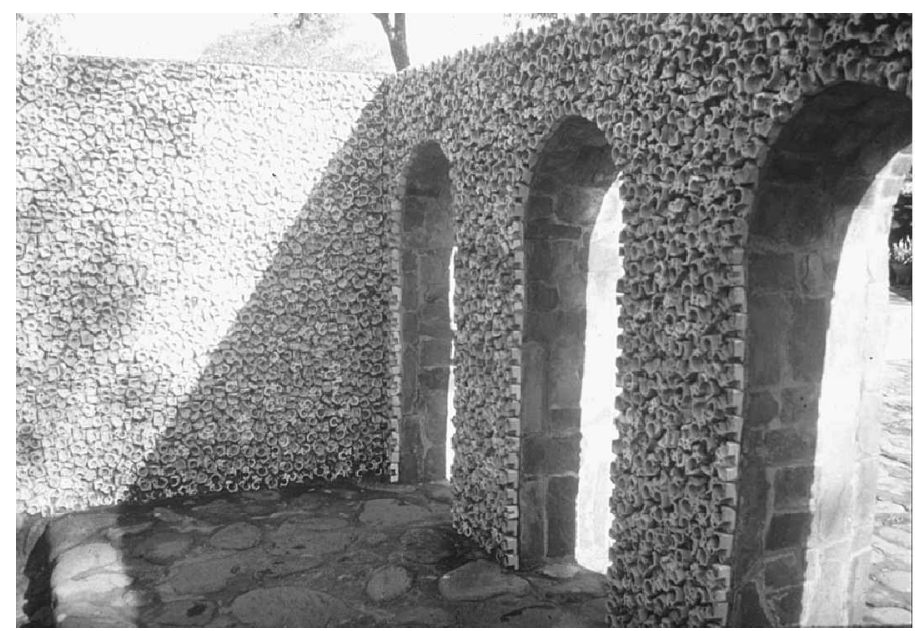

3. View from the Rock Garden, Chandigarh, India. (Photography by author.)

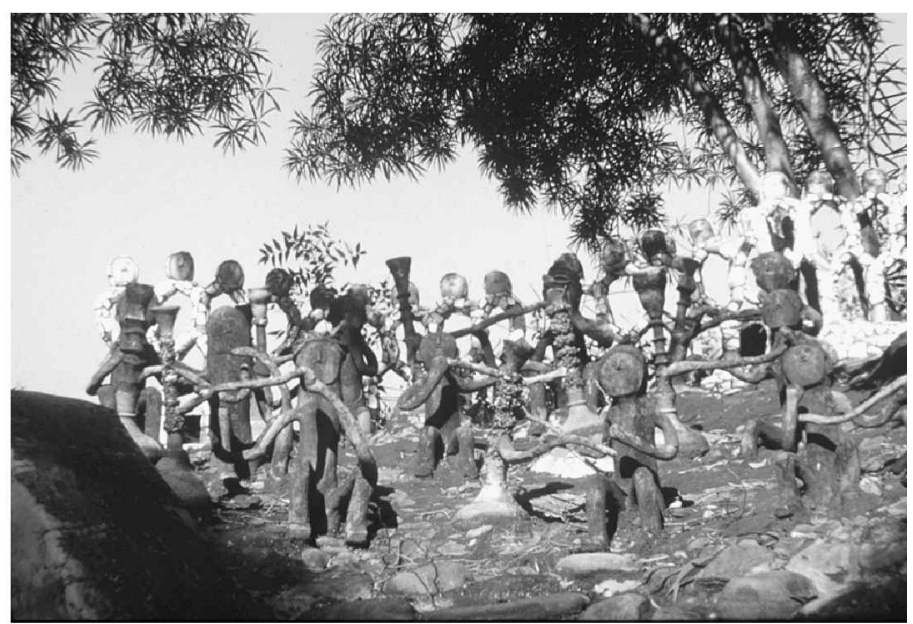

4. Figurines in the Rock Garden, Chandigarh, India. (Photograph by author.) with the non-West. The key terms that define non-Western architecture- "non-West" and "architecture"—are loaded with a-priori significations. Non-Western architecture is an identification that restructures both sides of the equation between the West and the non-West and architecture and nonarchitecture. A non-Western essence that is implicated in the term non-Western architecture (whether despised or idealized, for these are two sides of the same coin) disappears the moment it is named as such. For it is already named in other terms, terms that are possible only in relation to already established categories.

My questions then are: Are there possibilities of identification for (non-Western) architectures other than their idealized image? Can we conceive of non-Western architecture, nonarchitecture without the categories of surplus and lack? Can we attribute a productive plenitude rather than lack to the prefix "non"? To what extent is it possible to undo the architectural gaze? Is there any way to look at architecture differently? In exploring how notions of lack and excess have been instrumental in the construction of architecture's disciplinary boundaries, I looked at how non-Western and vernacular environments figured in two paradigmatic Western texts of international reputation. To address these questions I will turn to a non-Western architectural site that has not been widely addressed by Western scholarship: the Rock Garden in Chandigarh, India. It is one example, perhaps among numerous others, that provides fertile grounds to unread the founding principles of the architectural discipline. Unlike the previous examples, the Rock Garden is not and cannot be a paradigmatic case because it does not offer a frozen moment of (other) architectural truths and does not belong to any architectural type or category. I will explore it as a ground of architectural possibilities - an inspiring moment to ask other questions of architecture beyond the discipline's selfconstructed boundaries.

Located in a former site of industrial waste, the Rock Garden is the laborious product of a road inspector, Sh. Nek Chand. Notions of waste and excess reappear here, albeit different than in the case of
Rudofsky's Sudanese tribal settlement. The Rock Garden is literally made of waste: pots, bottles, broken objects, and all kinds of ceramic, metal, and plastic trash. Its labyrinthian experience provides fantasmatic paths of discovery. Unusual objects, textures, and surfaces bring about magical experiences (Figure 3). ${ }^{32}$ Pieces of broken plates, spare parts of sanitary appliances, and defective earthenware are transformed almost beyond recognition. The garden has its permanent inhabitants in the form of numerous figurines, both human and animal (Figure 4). Made of waste as well, and conspicuously genderless, these figurines are situated in miniature communities, dancing, greeting their viewers, or just standing in peace. They are silent witnesses of the possibility of seeing beauty in debris, life in death. Permanence and immortality-obsessions of the architectural discipline - take on a different meaning in the Rock Garden. Here, rather than belonging to a finished form, the notion of permanence points to a continuing process of translations and transformations. The Rock Garden flees from architecture's structuring reflection of cities, buildings, and open spaces. It bears testimony to the possibility of looking differently, seeing other than what is given to be seen. As such, it marks an instance of fertility and procreation rather than a statement of impeccable architectural principles.

In the Rock Garden, Rudofsky's statement that the philosophy and know-how of anonymous builders present the largest untapped source of architectural inspiration for industrial man is turned to its opposite. Here it is industry itself that has presented an untapped source of architectural inspiration for the local builder. Not only the proper categories of architecture but also those of industrial production are effectively undermined. The Rock Garden opens up a series of issues on the role of locality in architecture beyond regional(ist) and national(ist) constructs that are typical of non-Western architectural approaches. Here locality does not address any notion of cultural identity. There are no mandalas, no trace of "Indianness" as architectural convention would like to see, but an engagement with the immediacy of a given set of circumstances. Located in close proximity to Le Corbusier's parliamentary 
complex, the Rock Garden does not participate in a complementary or oppositional gesture. It is a silent interruption to the grand narrative of the masters - a silent refusal to participate.

The Rock Garden provides an architectural instance that effectively undermines the categorical imperatives of the architectural gaze in relation to non-Western architectures. It cannot be recuperated by the discourses that I exemplified through Fletcher's and Rudofsky's approaches. The Rock Garden is neither non-Western nor vernacular, as architectural discourse would have it. In reading canonical architectural texts, I explored the mechanisms that perpetuate the structural foundations of the architectural discipline in relation to its West/non-West division. The Rock garden is but one example that demonstrates that the binary categories of West and non-West, beauty and waste, lack and excess can be undone. I would argue then, that once conceptualized as a signification rather than a finite disciplinary field, architecture can be productively dismantled. Other architectures, then, do not exist in other places and other times. On the contrary, they are captured in the immediacy of the present, in the spatial productions of historically and psychically constructed bodies; in their engagement with the materiality of space. Other architectures question architecture's intolerance to difference, to the unthought, to its outside. Their imagination becomes possible when one is ready to see beyond the disciplinary borders whose regulations rely on notions of lack and excess.

In conclusion, my own use of the terms "West," "non-West," and particularly, "architecture" throughout this article calls for clarification. In criticizing such identity categories, my aim is not to find others to replace them. I am concerned less about the names themselves than how they are mobilized to perpetuate hegemonic discourses and practices. That the category of non-Western architecture cannot simply be abandoned in favor of a different name does not mean that it needs to be redefined. Any such definition helps but to draw other boundaries that will mark other inclusions and exclusions. There is no pure and virtuous space outside our present categories. ${ }^{33}$ The idea, then, is to accept the porousness and malleability of boundaries and identity categories and be aware of their strategic significance.

\section{Notes}

Different versions of this article appeared in a number of earlier presentations and publications. I presented a shorter version at the Cultural Studies Association of Australia Conference, Adelaide, December 1998. Earlier formulations of some of the ideas were presented at the annual meeting of the Society of Architectual Historians, Los Angeles, April 1998, and at Forum II: Architectural Education for the
Third Millenium,” Farmagusta, Cyprus, April 1998. “(Post)Colonial Architectural Encounters" will appear in Asian Architects, v. 2 (Singapore: Select, 1999). For a Turkish version of the latter, see Toplum ve Bilim, n. 79, Winter 1998, pp. 66-78.

* "Lack" and "excess" are terms that I borrow from psychoanalytical theory, which inspires this article. For a highly elaborated discussion of the architectural discipline from this perspective, see: Mirjana Lozanovska, Excess: $A$ Thesis on [Sexual] Difference and Architecture, unpublished Ph.D. Dissertation, Deakin University, 1994.

1. Karen Burns, "Architecture: That Đarrgerous Useless Supplement." In the proceedings of the conference Accessory/Architecture, held in Auckland, New Zealand, Jul. 1995, v. 2, pp. 49-56.

2. Elizabeth Grosz. "Architecture from the Outside." In Space, Time, and Perversion: Essays on the Politics of Bodies (New York: Routledge, 1990), pp. 125-137.

3. Here I use Judith Butler's analysis of sexual difference in an architectural context. In the light of Lacanian psychoanalysis, Butler argues that the feminine position is not only the other of a masculine desire but also represents or reflects that desire. As such, it is the site of a masculine self-elaboration. See: Judith Butler, Gender Trouble: Feminism and the Subversion of Identity (New York: Routledge, 1990), pp. 43-46.

4. Contemporary historians and theorists have addressed the constitution of the architectural canon from a broad scope of theoretical positions. From a historicist position, Spiro Kostof argues that all buildings should be included in the study of architecture and explained in relation to their broader historical context. See: Spiro Kostof, A History of Architecture: Settings and Rituals (New York: Oxford University Press, 1985), pp. 7-19. From a psychoanalytical feminist perspective, Mirjana Lozanovska uses the terms "autonomy," "metaphor," "vision," and "the fathers" to expose the discipline's founding assumptions. See: Lozanovska, Excess: A Thesis on [Sexual] Difference and Architecture. Miriam Gusevich, on the other hand, uses poststructuralist theory's premises to examine how the notion of autonomy is established by the institution of architectural criticism. See: Miriam Gusevich, "The Architecture of Criticism: A Question of Autonomy," in Drawing, Building, Text (New York: Princeton Architectural Press, 1991), pp. 8-24.

5. Jacques Lacan, The Four Fundamental Concepts of Psychoanalysis (New York: W. W. Norton, 1981), p. 106. I have largely benefited from Kaja Silverman's explanation of this notion in The Threshold of the Visible World (New York: Routledge, 1996).

6. Sir Banister Fletcher, A History of Architecture on the Comparative Method for the Student Craftsman, and Amateur (London: B. T. Batsford Ltd., 1954), 16th ed.; Bernard Rudofsky, Architecture without Architects: A Short Introduction to Nonpedigreed Architecture (New York: Doubleday, 1964).

7. The most prominent Western examples to study non-Western architectures before Fletcher are Viennese architect Fischer von Erlach's Entwurff einer Historischen Architecture of 1721 and James Fergusson's A History of Modern Styles in Architecture of 1862 and A History of Architecture of 1865-76. The former is primarily a collection of plates, more in the manner of a portfolio than a historical account. The accuracy of Erlach's drawings and reconstructions have been largely disputed by contemporary scholars. See: Hanno-Walter Kruft, A History of Architectural Theory from Vitruvius to the Present, Ronald Taylor, Elsie Callander, and Antony Wood, trans. (New York: Princeton Architectural Press, 1994), 183-185. Fergusson's work, on the other hand, has seen a number of reprints and is similar in scope to Fletcher's. What attracts me to the latter, as I shall elaborate below, is its self-conscious historical method. Besides Fletcher's and Fergusson's work, nonWestern architectural cultures attracted the attention primarily of their contemporary specialists who did field work in the colonized regions. For an extensive 
account of early twentieth-century Western scholarship on Javanese architecture, for example, see: Stephen Cairns, "Re-Surfacing: Architecture, Wayang, and the "Javanese House" in Gülsüm B. Nalbantoglu and Wong Chong Thai, eds., Postcolonial Space(s) (New York: Princeton Architectural Press, 1997), pp. 73-88.

8. Fletcher, A History of Architecture, p. 888.

9. James Fergusson, Encyclopedia of World Architecture (New Delhi: Aryan Books International, 1998 reprint), p. 7.

10. Ibid., p. 6. An anonymous reviewer of an earlier version of this article has pointed out that nineteenth-century English historians were originally at a loss when confronted with their own Gothic architecture as much as with other architectural cultures, as it was also excessive and hard to categorize historically. Fergusson's categorization of the Gothic with non-Western architectural cultures is hardly surprising in this respect.

11. In one of the most quoted parts of Alberti's treatise, he refers to beauty as one of the fundamental attributes of architecture and describes it as the "harmony of all the parts, in whatsoever subject it appears, fitted together with such proportion and connection, that nothing could be added, diminished or altered, but for the worse." See: Leone Batisti Alberti, The Ten Books of Architecture, reprint of the 1755 Leoni edition (New York: Dover Publications, 1986), p. 113. For Alberti, beauty is a self-sufficient, immaculate, and intact entity. The beautiful object neither lacks, nor is in excess of any component.

12. Fletcher, A History of Architecture, pp. 888, 893, 961. I have argued elsewhere that Fletcher's text can be read in other ways to suggest the recognition of radical alterity in non-Western architectural cultures. Here I want to emphasize his explicit references to notions of lack and excess. See my "Towards Postcolonial Openings: Re-reading Sir Banister Fletcher's History of Architecture," Assemblage 35, Apr. 1998, pp. 6-17.

13. James Fergusson, History of Indian and Eastern Architecture (New Delhi: Sri Devendra Jain for Munshiram Manorharlal, 1972 [reprint of revised 1910 edition; first published in 1876]), p. 4.

14. Here I reproduce Kaja Silverman's explanation of lack and plenitude in terms of the identification of the female subject. See: Kaja Silverman, The Threshold of the Visible World (New York: Routledge, 1996), p. 33.

15. A recent article by Paul Walker on Fletcher's work on the 1893 Chicago World's Columbian Exposition supports my argument. Walker focuses on the omission of the Japanese Ho-o-den from Fletcher's analyses. He argues that for Fletcher, the Ho-o-den was uncannily similar to the architectures of the West and, if acknowledged, would blur the neat distinction between historical and nonhistorical styles. See: Paul Walker, "The Invisible 'East': Fletcher and the Unseen Ho-o-den," Self, Place and Imagination: Cross-Cultural Thinking in Architecture, Proceedings of the Second Symposium by the Centre for Asian and Middle Eastern Architecture, The University of Adelaide, Australia, 1999, pp. 145-151.

16. Paul Walker offers an extensive analysis of the status of Asia and the $\mathrm{Pa}$ cific in Fletcher's career and surfaces the disruptions and ambivalences that are suppressed by the latter's submission of non-Western architectural cultures to the same framework of analysis as Western ones. See: Paul Walker, "Vagrancy: Asia and the Pacific in Sir Banister Fletcher's A History of Architecture, in Building, Dwelling, Drifting: Migrancy and the Limits of Architecture, Proceedings of the third Other Connections Conference, University of Melbourne, Jun. 26-29, 1997, pp. 356-362.

17. Robin Middleton and David Watkin, Neoclassical and 19th Century Architecture (New York: Rizzoli, 1987), p. 372.

18. Quoted in John Sweetman, The Oriental Obsession (Cambridge, UK: Cambridge University Press, 1988), p. 238.
19. In 1941, Rudofsky was invited by the MoMA to propose an exhibition to which he responded with a portfolio of his photographs of vernacular architecture. MoMA rejected the proposal and the photographs remained in the archives until 1964. See: Bernard Rudofsky, The Prodigious Builders: Notes Towards a Natural History of Architecture (New York: Harcourt Brace Jovanovich, 1977), pp. 36668. Both this account and the architectural context of Rudofsky's position are explained in: Felicity Scott, "Underneath Aesthetics and Utility: The Untransposable Fetish of Bernard Rudofsky," Assemblage, n. 38, Apr. 1999, pp. 59-89. Hanno-Walter Kruft explains that "dissatisfaction with functionalist attitudes, indeed with planned architecture of any kind, showed itself in the interest that was aroused by an exhibition mounted by the Museum of Modern Art in New York in 1964 under the title Architecture without Architects." See: Kruft, A History of Architectural Theory, p. 439.

20. For a brief account of the history of architectural interest in vernacular studies, see: Eleftherios Pavlides, "Architectural Approaches and Concepts," in Encyclopedia of Vernacular Architecture, Paul Oliver, ed. (Cambridge: Cambridge University Press, 1997), v. 1, pp. 12-15.

21. Rudofsky, Architecture without Architects, p. 1.

22. Scott, "Underneath Aesthetics and Utility," p. 82.

23. Quoted in Scott, ibid., p. 69.

24. Rudofsky, Architecture without Architects, p. 7.

25. Pavlides, "Architectural Approaches and Concepts," pp. 14-15.

26. Oliver cites Shelter and Society, an book edited by him and published in 1969 , as an attempt to develop an alternative position to Rudofsky's. See: Paul Oliver, "Preface," in Encyclopedia of Vernacular Architecture, v. 1, p. vii.

27. Paul Oliver, Dwellings: The House Across the World (Austin: University of Texas Press, 1987), pp. 14-15. I would like to point to the alarming ease by which the term culture enables Oliver to unify different parts of the globe. $\mathrm{He}$ emphasizes the differences between societies and is clearly interested in the expression of these in built forms. What Oliver means by difference, however, turns out to be diversity. Homi Bhabha points to the distinction by explaining that cultural diversity is a category of comparative ethics and aesthetics that emphasizes liberal notions of multiculturalism and cultural exchange; cultural difference, on the other hand, "focuses on the problem of the ambivalence of cultural authority-the attempt to dominate in the name of a cultural supremacy which is itself produced only in the moment of differentiation." See: Homi Bhabha, "The Commitment to Theory," in The Location of Culture (London: Routledge, 1994), p. 34.

28. Rudofsky, Architecture without Architects, pp. 40-41.

29. Roland Barthes, Camera Lucida, Richard Howard (London: Fontana paperbacks, 1984), pp. 10-15.

30. Kaja Silverman, The Threshold of the Visible World (New York: Routledge, 1996), pp. 196-202.

31. This point is addressed in detail by James Clifford in an article on a 1984-85 MoMA exhibition entitled "Primitivism' in 20th Century Art: Affinity of the Tribal and the Modern." See: James Clifford, The Predicament of Culture: Twentieth Century Ethnography, Literature and Art (Cambridge, MA: Harvard University Press, 1988), pp. 189-214.

32. At one level, my own photographic representations of the Rock Garden bear the burden of architectural representation that I argue in this paper. I must emphasize that they are not meant to construct a finite architectural reality but should be seen as what they are: photographic representations of partial scenes from a garden.

33. Stephen Cairns makes a similar argument in "Re-surfacing," p. 88. 